\title{
The Function of the Tegumental Glands in the Statocyst of Homarus vulgaris.
}

\author{
By \\ D. Lang, B.Sc., and C. M. Yonge, D.Sc., \\ Department of Zoology, University of Bristol.
}

With 4 Figures in the Text.

\section{Introduction.}

Prentiss (1901), in the course of his study of the otocyst (or statocyst as it will be referred to here) of the Decapod Crustacea, found that the statoliths consist of sand grains which are renewed after each moult. These may lie free in the cavity of the statocyst or be attached to the sensory setæ. In the crayfish, Cambarus affinis, and in the megalopa stage of the crab, Carcinus monas, Prentiss found that the sand grains were secured to the setæ by a substance which he considered (though without any direct evidence) to be secreted by the tegumental glands present beneath the integument of the sac. In Palcomonetes vulgaris, though he was unable to find similar glands, he found fine ducts which penetrated the integument and these he regarded as the outlets for the glands he could not identify. Herrick (1911) found tegumental glands in the sub-epithelial tissues beneath the integument of the statocyst in Homarus americanus and he accepted Prentiss' view as to their function; Kinzig (1914) came to a similar conclusion after the study of a large number of Decapods.

It has recently been shown by Yonge (1932) that the tegumental glands in Homarus vulgaris and in other Decapod Crustacea secrete the cuticle which everywhere covers the underlying and much thicker chitin which is formed by the chitinogenous epithelium. The cuticle is totally different in nature from the chitin and the two can be distinguished by a variety of chemical and physical tests. Yonge also pointed out that the primary function of the glands was not necessarily incompatible with accessory functions such as the binding of the eggs to the pleopods of the female.*

The discovery of the primary function of the tegumental glands

* This has since been confirmed and forms the subject of a forthcoming paper. C.M.Y. 
enables the re-investigation of Prentiss' theory to be profitably undertaken. The glands situated around the statocyst may be responsible only for the formation of the cuticle which lines the integument of the sac, on the other hand if the substance which binds the statoliths to the sensory setæ in Homarus vulgaris (the experimental material used in this research) can be shown to have the same properties as the cuticle, it is not unreasonable to assume that it is formed by the same agency.

\section{Structure of the Statocyst.}

The statocyst in Homarus vulgaris is situated, as in all Decapod Crustacea, in the basal segment of the first antenna. It consists of an

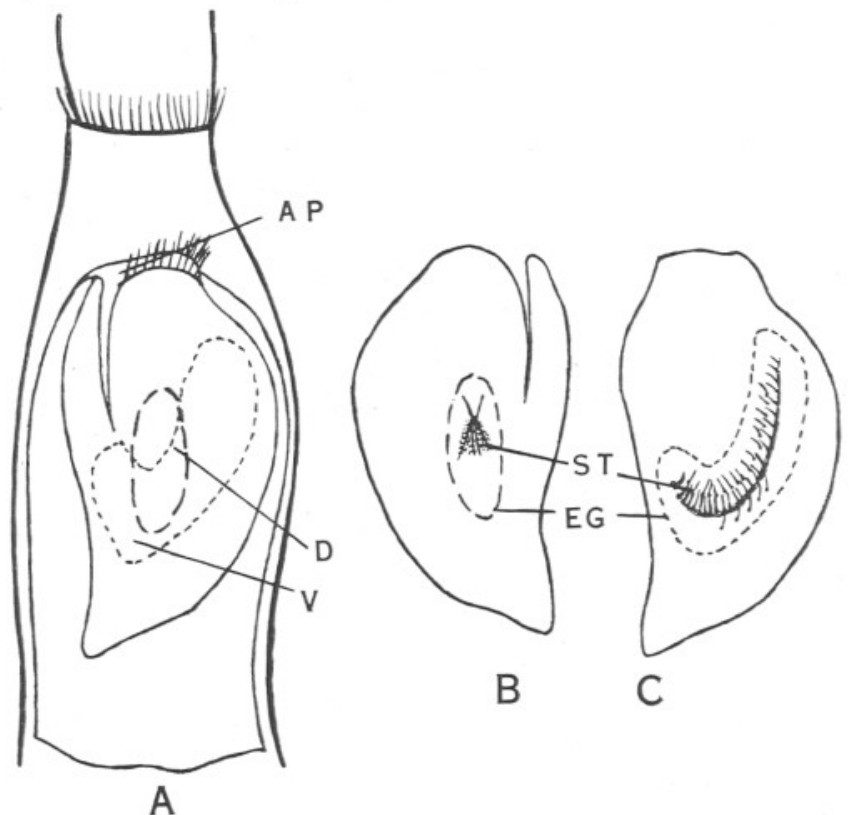

FIG. 1.-Semi-diagrammatic representation of statocyst of Homarus vulgaris. $\times 4$. A, dorsal view of basal segment of first antenna of right side showing extent of statoeyst ; B, roof of cavity ; C, floor of cavity ; AP, aperture ; D, dorsal area of setæ and attached sand grains: EG, extent of sand grains indicated by broken lines; ST, sensory setæ; V, ventral area of setæ and attached sand grains.

ectodermal invagination on the dorsal side which opens by a small aperture at the anterior end (Fig. 1, AP). Within the cavity are two clusters of sensory setæ (ST). One of these (V) extends over a horseshoe shaped area on the ventral wall, the setæ (Fig. 1, C) being arranged in two rows with an additional third, irregular row on the convex side of the curve. The other (Fig. 1, B) consists of a group of some five setæ situated on a small papilla on the dorsal wall (D) in about the middle line. These setæ are longer than those of the ventral wall. 
The setæ (Fig. 3), which have been described in detail by Prentiss, Kinzig, and earlier workers, are hollow, plumose structures with a spherical membrane (M) at the base which permits of a wide range of movement. The setæ in H. vulgaris are not bent at an angle of $120^{\circ}$ as described by Prentiss for Palæmonetes. The sand grains (S) forming the statoliths are attached to the setæ, the pinnules of which interlock to form a "wickerlike mesh " (Prentiss), by masses of a hyaline secretion (H). When the statocyst is opened up the sand grains so embedded appear as a wide, irregular semicircle on the floor of the cavity and as an oval mass on the roof. Owing to the extent of the hyaline secretion the area occupied by the sand grains (Fig. 1, EG) is considerably greater than that occupied by the setæ (Fig. 1, ST). The majority of these sand grains become detached from the setæ when they are removed, but examination shows that they are bound together by strands of the hyaline secretion.

\section{The Tegumental Glands.}

The tegumental glands which occur in the sub-epithelial tissues around the statocyst have the usual structure (see Yonge, 1932, and earlier

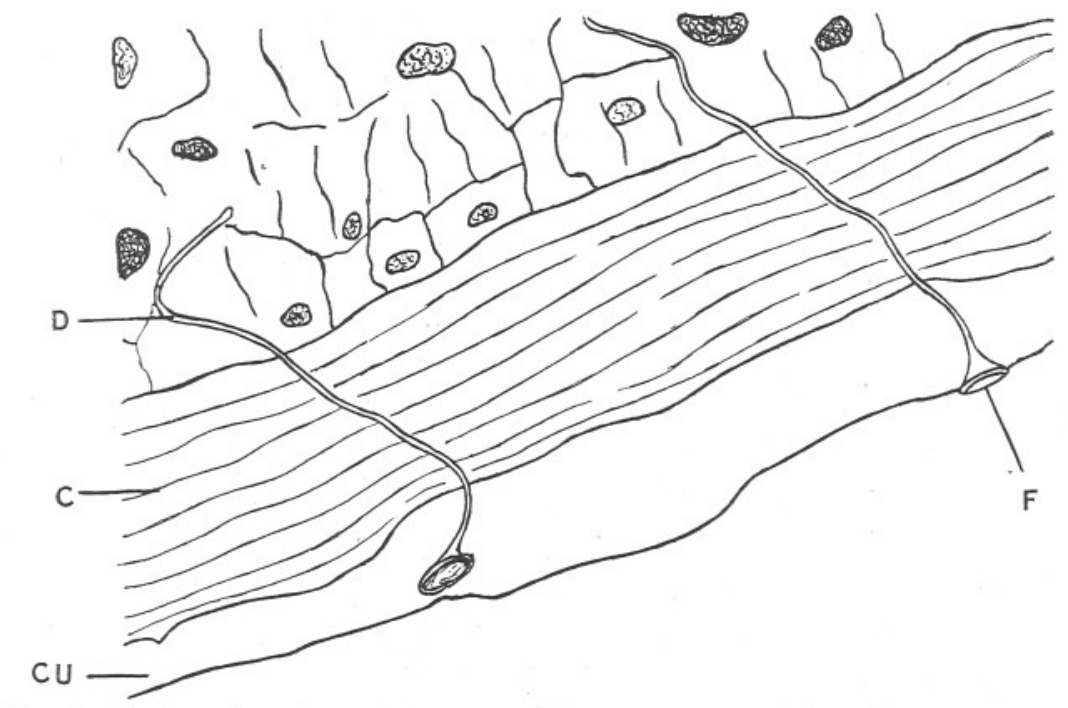

FrG. 2.-Section through wall of statocyst showing passage of ducts from tegumental glands through integument. $\times 500$. C, chitin; CU, cuticle; D, duct; F, funnelshaped opening of duct.

workers quoted by him). In the anterior region they are especially numerous beneath the dorso-lateral wall (i.e. between the dorsal cluster of setæ and the lateral arm of the ventral horse-shoe area which extends further to the anterior than does the median arm). In the middle region, where both arms of the horse-shoe are cut through in section, as well as 
the dorsal area, the glands occur beneath both the dorso-lateral and dorsomedian walls. Further to the posterior where, owing to the asymmetry of the horse-shoe, the ventral setæ are situated near to the median wall of the statocyst, the glands are most numerous beneath the dorso-median wall. Although the glands never lie actually beneath the setæ they do appear to be definitely associated with them because they vary in position quite regularly in accordance with the distribution of the setæ.

The ducts from the glands pass through the tissues and then penetrate the integument. They possess one highly characteristic feature, a wide funnel-shaped opening (Fig. 2, F) at the surface of the integument opening into the cavity of the statocyst. Openings of this type never occur in other regions of the integument where the glands are concerned solely with the production of the bounding cuticle.

\section{Nature of the Hyaline Secretion.}

A variety of tests corresponding to those employed by Yonge (1932) for the identification of the cuticle and the chitin were applied to the hyaline secretion which secures the sand grains, or statoliths, to the sensory setæ. The nature and results of these tests are outlined in Table I, the statements in columns 2 and 3 being taken from Yonge.

\section{TABLE I.}

\begin{tabular}{|c|c|c|c|}
\hline $\begin{array}{c}\text { Test. } \\
\text { Conc. HC1 }\end{array}$ & $\begin{array}{l}\text { Chitin. } \\
\text { Dissolves } \\
\text { immediately. }\end{array}$ & $\begin{array}{l}\text { Cuticle. } \\
\text { Dissolves very } \\
\text { slowly. }\end{array}$ & $\begin{array}{l}\text { Hyaline Secretion. } \\
\text { Dissolves very } \\
\text { slowly. }\end{array}$ \\
\hline Hot $40 \% \mathrm{NaOH}$ & H Insoluble. & $\begin{array}{l}\text { Dissolves } \\
\text { immediately. }\end{array}$ & $\begin{array}{l}\text { Dissolves } \\
\text { immediately }\end{array}$ \\
\hline Iso-electric point & at $\mathrm{pH} 3.5$ & $\mathrm{pH} 5 \cdot 1$ & $\mathrm{pH} 5 \cdot 1$ \\
\hline Mallory $\quad$. & Stains blue. & Stains red. & Stains red. \\
\hline Sudan III & Not stained. & Stains red. & Stains red. \\
\hline
\end{tabular}

It will be noted that in every case the reactions of the hyaline secretion are identical with those of the cuticle and different from those of the chitin. The action of $\mathrm{NaOH}$ on the secretion is well illustrated by the difference between the appearance of the setæ with adhering sand grains before and after treatment. This is shown in Fig. 4, A and B. Not only has the hyaline secretion disappeared in $\mathrm{B}$, but the setæ have lost their rigid appearance owing to the dissolution of the bounding cuticle which is largely responsible for this. The underlying chitin has not been attacked. There is the same difference between the iso-electric point of the hyaline secretion and that of the chitin as there is between the iso-electric points of the cuticle and the chitin and with the same consequent differences 
between the staining reactions as exemplified by the anilin blue (basic) and the acid fuchsin of the Mallory. Finally, the action of Sudan III indicates that the lipoid constituent, so characteristic of the cuticle and so all-important in controlling the permeability of the uncalcified integument (Yonge, 1935), is also present in the hyaline secretion.

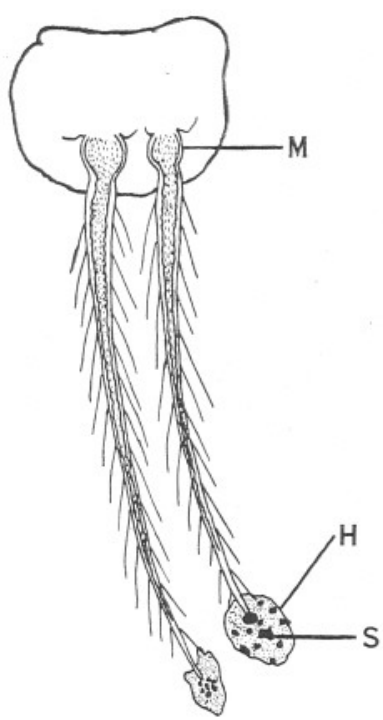

Fig. 3.- Sensory setæ with attached sand grains. $\times 48 . \mathrm{H}$, hyaline secretion; M, spherical membrane; $\mathrm{S}$, sand grains attached to setæ by hyaline secretion.

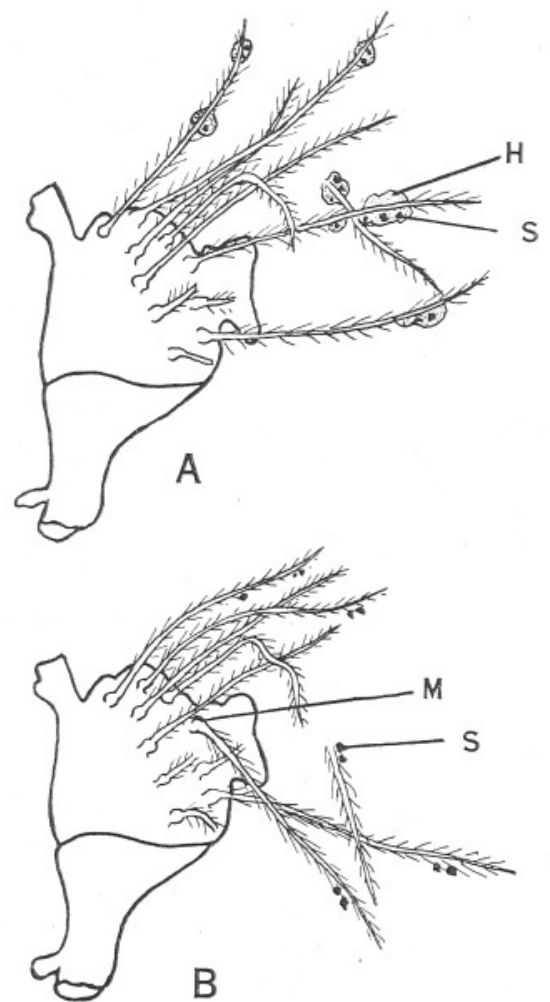

FIG. 4.-Group of setæ with attached sand grains. A, before, and B, after treatment, with hot $40 \% \mathrm{NaOH} . \times 24$. Other lettering as before.

\section{Discussion.}

The evidence presented in this paper gives very considerable support to the view of Prentiss that the hyaline substance which secures the statoliths to the setæ in the statocysts of the Decapod Crustacea is secreted by tegumental glands. The most significant data are provided by the reactions of the hyaline secretion which agree in every respect with those of the cuticle. The tegumental glands situated around the statocyst, though they do not occur actually beneath the setæ, are arranged 
in definite relation to these. They are similar in every respect to those which secrete the bounding cuticle, but this is also true of those which secrete the cement which binds the eggs to the pleopods of the female. The question arises, how is it that the secretion of these glands enters the cavity of the statocyst and there cements the sand grains on to the setæ, and does not spread out over the surface of the integument like the secretion of the great majority of these glands? The probable explanation is that these particular tegumental glands secrete immediately after and not some little time before the actual moult. As shown by Yonge (1932), the tegumental glands which form the cuticle begin to secrete some weeks before the actual moult (in the case of $H$. vulgaris); the first indications of the new cuticle being found when the first indications of the gastroliths appear. By the time the old integument is ready to be cast the cuticle (though not the underlying chitin) is fully formed and the glands have begun to degenerate. In other words the cuticle is fully formed before it is exposed. Although there is no experimental evidence to support this statement, it is not unreasonable to assume that if these glands poured out their secretion after the moult, so that it was exposed at once to the action of the surrounding sea water, it would not spread over the surface of the integument. Sand grains lying in the cavity of the statocyst would be entangled with this secretion and would adhere to the only projecting objects in the cavity, namely the setæ. The secretion, as in the case of the cuticle and the cement which secures the eggs, quickly sets hard after exposure, and in this way the statoliths would be firmly secured to the sensory setæ. The wide, funnel-like openings of the ducts indicate that the secretion is set free into the cavity of the statocyst as suggested here.

This research is of interest, not only because it lends great support to the theory originally put forward by Prentiss, but because it draws further attention to the great importance of the tegumental glands in the Crustacea ; glands which are unique in having accessory functions almost as important as their primary one.

The authors wish to acknowledge financial assistance received from the Colston Research Fund of the University of Bristol. 


\section{SUMMARY.}

1. The general structure of the statocyst and the combined sensory setæ in Homarus vulgaris have been described.

2. The statoliths consist of sand grains attached to the setæ by a hyaline secretion.

3. Numerous tegumental glands occur in the sub-epithelial tissues. Though not situated beneath the setæ, their distribution varies in accordance with that of the setæ. Their ducts have characteristic funnel-shaped endings, opening into the cavity of the statocyst.

4. The hyaline secretion agrees in all its reactions with the cuticle, never with the chitin.

5. The conclusion is reached that the hyaline secretion is formed by these tegumental glands and that this constitutes an important accessory function of these glands.

\section{REFERENCES.}

Herrick, F. H. 1911. Natural History of the American Lobster. Bull. U.S. Bur. Fish., XXIX, pp. 149-408.

Kinzig, H. 1914. Untersuchungen über den Bau der Statocysten einiger dekapoden Crustaceen. Verh. Naturhist-Medizin. Ver. Heidelberg, N.F., XIV, 1-90.

Prentiss, C. W. 1901. The Otocyst of Decapod Crustacea : its Structure, Development, and Functions. Bull. Mus. Comp. Zool., Harvard, XXXVI, pp. 167-251.

Yonge, C. M. 1932. On the Nature and Permeability of Chitin. I.The Chitin Lining the Foregut of Decapod Crustacea and the Function of the Tegumental Glands. Proc. Roy. Soc. Lond., B, CXI, pp. 298-329.

Yonge, C. M. 1935. On the Nature and Permeability of Chitin. II.The Permeability of the Uncalcified Chitin Lining the Foregut of Homarus. (In Preparation.) 
3 